Grand Valley State University

ScholarWorks@GVSU

\title{
The Spirit of Family Business: A Comparative Analysis of Anglo, Germanic and Nordic Nations
}

Vipin Gupta

Simmons College School of Management, gupta05@gmail.com

Nancy M. Levenburg

Grand Valley State University, levenbun@gvsu.edu

Lynda Moore

Simmons College

Jaideep Motwani

Grand Valley State University, motwanij@gvsu.edu

Thomas V. Schwarz

Grand Valley State University, schwarzt@gvsu.edu

Follow this and additional works at: https://scholarworks.gvsu.edu/mgt_articles

Part of the Business Commons

\section{ScholarWorks Citation}

Gupta, Vipin; Levenburg, Nancy M.; Moore, Lynda; Motwani, Jaideep; and Schwarz, Thomas V., "The Spirit of Family Business: A Comparative Analysis of Anglo, Germanic and Nordic Nations" (2011). Peer

Reviewed Articles. 2.

https://scholarworks.gvsu.edu/mgt_articles/2

This Article is brought to you for free and open access by the Management Department at ScholarWorks@GVSU. It has been accepted for inclusion in Peer Reviewed Articles by an authorized administrator of ScholarWorks@GVSU.

For more information, please contact scholarworks@gvsu.edu. 
The spirit of family business:

\title{
A comparative analysis of \\ Anglo, Germanic and \\ Nordic nations
}

\author{
Vipin Gupta \\ California State University-San Bernardino, USA
}

\author{
Nancy M. Levenburg \\ Grand Valley State University, USA

\section{Lynda Moore} \\ Simmons College School of Management, Boston, USA
}

\section{Jaideep Motwani}

Grand Valley State University, USA

\section{Thomas Schwarz}

California State University-Fullerton, USA

\begin{abstract}
Using GLOBE classification and findings, this paper compares the family characteristics and work cultures of family businesses in Anglo, Germanic, and Nordic cultures. Results indicate differing patterns in terms of the involvement of the family in the family business and other key organizational dimensions. While all three regions share their weak family orientation, the Nordic and Germanic regions share stronger future orientation and uncertainty avoidance. The Anglo and Germanic regions share stronger performance orientation and the Nordic region stands out for its low power distance and low assertiveness. Overall, the characteristics of family businesses in the three regions may be associated with the distinctive regional cultures suggesting support for the presence of culturally implicit theories in the family business characteristics.
\end{abstract}

\section{Keywords}

Anglo, comparative analysis, family business, Germanic, Nordic

\section{Corresponding author:}

Vipin Gupta, Professor and Co-director, Global Management Center, JB 404, College of Business and Public Administration, California State University, 5500 University Parkway, San Bernardino, USA.

Email : gupta05@gmail.com 


\section{Introduction}

Family businesses are the dominant form of business organization in most economies yet the literature on families and family businesses in non-Anglo cultures has been both scant and scattered (see e.g. Baring, 1992; Pistrui et al., 2000). Typically deeply rooted in their local cultures, communities, and institutions, and dependent on the family's resources for leadership, these family firms are influenced by the specific cultural context within which they exist. As Chrisman et al. (2003: 442) note, 'Family businesses ... bring together so starkly the economic and noneconomic realities of organizational life'. Dunemann and Barett (2004: 25) also observe, 'From the earliest basic childhood experiences to those that flow with more specific connection to the family business, successors, for good or ill, are shaped by culture and formative influences surrounding them.' In order to truly understand the dilemmas and decisions these family businesses face, they must be examined within the cultural contexts in which they breed, nourish, and grow.

Fortunately, recent developments in cultural measurement methodology offer tools to understand family businesses through the use of regional clusters and comparative lenses (Gupta and Hanges, 2004; Ronen and Shenkar, 1985). For instance, the Protestant cultures of the world are partitioned into three distinct regional clusters - Nordic and Germanic clusters within the Northern European region, and the Anglo cluster that is dispersed across several continents based on the migration from England (Hofstede, 2001; House et al., 2004). The term Nordic refers to the five Scandinavian countries, with their model of welfare state and common history, culture, and religion and similar languages (Einola and Turgeon, 2000). These nations were the ancient land of Norsemen, and were most influenced by the Lutheran interpretation of Christianity (Einola and Turgeon, 2000). In contrast, the distinctive Germanic culture can be traced to at least 5400 BC (Schake, 1998). Tacitus (AD 55-117) wrote a short account, Germania, of the people of Germany, and described these people as possessing a love of freedom and fighting. During the post medieval times, the Protestant form of Christianity evolved as a distinct German interpretation of life. Traditional Germanic values include orderliness, straightforwardness, honesty, and loyalty (Gupta and Hanges, 2004).

The purpose of this research is to enhance the existing body of literature by analyzing variations in family business characteristics in three selected regions - Nordic Europe, Germanic Europe, and the Anglo region. These three regions are selected because they share significant similarities in their cultural dimensions, as shown by the GLOBE Program (House et al., 2004). These similarities derive partly from the shared influence of the spirit of Protestant form of Christianity in these three clusters. Specifically, these three clusters are: (1) the Anglo cluster including Australia, New Zealand, Canada, the USA, and the UK; (2) the Nordic cluster including Finland, Sweden, Denmark, Iceland, and Norway; and (3) the Germanic cluster including Germany, the Netherlands, Austria, and Switzerland.

This paper is based on the CASE (Culturally sensitive Assessment Systems and Education) Project (Gupta and Levenburg, 2010). The CASE Project reviewed literature on family businesses in each region and systematically analyzed 110 articles on family businesses authored by over 200 scholars worldwide. Nine etic dimensions were identified, and are summarized in Table 1 (Gupta et al., 2008a, b, c). (Etic is a term that is used to describe items that are being analyzed without considering their role as a structural unit in a system. Emic, in contrast, is a term that is used when items are being analyzed with respect to their role as a structural unit in a system.)

With this framework, we review literature related to the typology of family business characteristics and the comparative studies of family businesses. We describe the research design 
Table I. Nine etic dimensions of the CASE Project

\begin{tabular}{ll}
\hline Dimension & Description \\
\hline Regulated boundary & $\begin{array}{c}\text { The criteria for the family business' access to family and community } \\
\text { resources are clearly regulated; the access to these resources is not } \\
\text { unregulated. } \\
\text { Family and community resources are involved only if it makes business } \\
\text { sense; the involvement of these resources is not guided by primarily } \\
\text { family interests. } \\
\text { Family business breaks out to access resources outside the family and } \\
\text { home community; it is not tied to only the family and home com- } \\
\text { munity for core resources. } \\
\text { Fridging relationships } \\
\text { Frganizational professionalism } \\
\text { levels; these are not limited to only the lower levels or to only select } \\
\text { parts of the organization. } \\
\text { Fegulated family power } \\
\text { family; family - as a collective or a divisive entity - does not create } \\
\text { uncertainty for it. } \\
\text { The successors must demonstrate competence to earn employment } \\
\text { and leadership in the family business; kinship alone does not create } \\
\text { the privilege to be employed and to lead the family business. } \\
\text { Women family members play important strategic roles in the family } \\
\text { business; they are not merely silent and invisible members of family } \\
\text { in business. }\end{array}$ \\
Family business has access to the reservoir of family and \\
community resources to wither temporary crisis or to overcome \\
more enduring challenges; it is not without any patient and loyal \\
capital. \\
Family business evolution is founded on the co-specialized and \\
dedicated resources, such as deep experiences and localized \\
endowments.
\end{tabular}

used to develop a sample of articles for content, analyzing the characteristics of family businesses in three selected regional clusters. Thereafter the cultural characteristics of those clusters are described using GLOBE methods, and the prevalence of the family businesses in each cluster is reviewed. Next, the characteristics of the family businesses in each of the three clusters in terms of the nine etic CASE dimensions are reviewed. The discussion section strives to identify common and varying cultural elements as a basis for the observed family business characteristics. In-depth implications of the study are examined for four domains of cross-cultural research: the convergence/divergence debate, the spirit of Protestantism discourse, the literature on culturally implicit theories, and family business management. Finally, some limitations of the research and conclusions are presented.

\section{Literature review}

Currently, there exist few typologies of family business characteristics. Those that exist are based on the review of anecdotal research, and have not been empirically tested. Moreover, those typologies 
are oriented toward explaining the differences between family and non-family businesses, rather than explaining the cross-cultural differences amongst the family businesses. Harris et al. (1994) reviewed the strategy literature and identified the following typology of the characteristics of family businesses that distinguish them from non-family businesses: 'inward' orientation; slower growth and less participation in global markets; long-term commitment; less capital intensive; importance of family harmony; employee care and loyalty; lower costs; generations of leadership; and the board's influence on implementation. No specifics on the mechanics of these characteristics, and how they may differ across cultures, were offered. Without such specifics, the authors - not surprisingly - concluded that 'the assessment of these family business characteristics and their influence on strategy leaves more questions than answers' (Harris et al., 1994: 171).

Some studies have examined the typologies of family business characteristics in terms of four typical stages in the growth of a family business. Gersick et al. (1997) analyzed characteristics of the family firm in each stage, and the implications regarding effective management in each stage. Similarly, Lussier and Sonfield (2004) reviewed the literature to identify eleven characteristics that are likely to differ amongst the first versus subsequent generation of family firms. These include the inclusion of non-family members, the inclusion of women family members, the use of team-style management, conflict and disagreement between family members, the formulation of specific succession plans, the use of outside consultants, advisers, and professional services, the time engaged in strategic management activities, the use of sophisticated methods of financial management, the consideration of going public, the influence of the original founder, and the use of debt vs equity financing. Their findings, however, indicate that the hypothesized variables did a poor job of explaining the generational differences amongst the family businesses, and the accuracy of discriminating among generations was only 60 percent.

In addition to the lack of an empirically substantiated cross-cultural typology of family businesses, there is also a deficiency of the cross-cultural comparisons of family businesses. Some early comparative studies have used a case approach to study family firms in a limited sample of nations. For instance, Barbot et al. (2005) compared father-daughter succession in France vs Tunisia. However, systematic comparisons of family businesses across regions have not yet been undertaken.

\section{Research design}

In order to systematically address our research objective of comparing family business characteristics among regions, we applied the following data collection procedures. A call for papers was issued throughout the international research community that clearly outlined the project guidelines, themes, and clusters. Using a variety of contact databases, the call for papers was distributed to all family business centers, organizations, institutes, and so on around the world and to faculty members researching or teaching family business-related topics. At the same time, meta research was conducted on the existing literature to identify possible contributors who had previously published papers on family business topics, particularly in global settings. A special invitation was sent to these writers to solicit their interest in participating in the project.

After receiving submissions for each cluster, we engaged in a content analysis and thoroughly screened each manuscript to obtain a representative sample. Specifically, the editors of the CASE Project analyzed each manuscript using the following criteria: application field, research methodology, data, level of analysis, focus of study, related constructs, and variables. On average, twenty submissions were received per cluster. After the screening, an average of ten submissions were retained per cluster, with instructions for revising and editing issued to submitters. This content 
analysis helped to not only identify the family business research currently being undertaken in each cluster, but also unveil the most frequently studied constructs and the related variables.

\section{Descriptions of Anglo, Germanic and Nordic clusters}

The distinguishing features of the three clusters, based on the seminal GLOBE book, Culture, Leadership, and Organization (House et al., 2004) and the CASE Project follow.

\section{Anglo cluster}

The GLOBE results suggest that the Anglo culture is distinguished by its strong performance orientation. It practices a weak form of family orientation, seen as impeding transparency and due diligence. Yet, the Anglo cluster strongly believes in the value of family orientation and of gender egalitarianism, though not in the values of institutional collectivism and uncertainty avoidance - as institutions and dogmas tend to impede flexibility and change (Gupta and Hanges, 2004).

Family businesses are an important form of organization in the Anglo cluster. Seventy- five percent of the 800,000 companies in Australia (Baring, 1992), 76 percent of the top 8000 companies in the UK (Stoy Hayward, 1989), and approximately 90 percent of all US firms (Pistrui et al., 2000) are estimated to be family businesses. Gupta et al. (2008a) conclude that most family businesses in the cluster seek to assure transparency and due diligence by regulating the involvement of family members, and strive to build capabilities for flexibility and change, in order to effectively compete with non-family businesses that dominate in an ever-changing, value-driven marketplace.

\section{Germanic cluster}

The GLOBE results suggest that the Germanic societies practice strong uncertainty avoidance, performance orientation, future orientation, and assertiveness. Though people idealize change, the society itself is enmeshed in order, structure, and rules, and operates as a well-oiled machine. Similarly, while the present and the material is idealized, the underlying behavior is focused on responding to the transcendental calling to perform, and to be assertive if need be. Other distinctive characteristics include weak family and institutional collectivism and low humane orientation. The concept of individual is strong, and any sense of obligations to the family, group, or to the broader institutions is avoided (Gupta and Hanges, 2004).

Family businesses are pervasive in Germanic cultures. Eighty percent of all firms in the Netherlands (Flören, 1998) and 85 percent of all businesses in Switzerland (Neubauer and Lank, 1998) are estimated to be family businesses. Gupta et al. (2008b) conclude the Germanic family businesses receive high regard and glorification from families and communities. Involvement of both male as well as female members of the family is seen as an indicator of family prestige. Continuity of this involvement across generations is valued.

\section{Nordic cluster}

The GLOBE results suggest that the societies in Nordic Europe cluster practice high levels of uncertainty avoidance, future orientation, institutional collectivism, and gender egalitarianism, and low levels of power distance and assertiveness. The social ideals include moderation of rules and structuring, balancing the future orientation with spontaneity, and a concept of personhood, where emphasis is on the individual's self-expression and identity (Gupta and Hanges, 2004). 
Family businesses are a dominant form of organization amongst the small and medium enterprises in the Nordic region, and many of the larger family businesses have been at the forefront of shaping regional and national development in the region. Gupta et al. (2008c) conclude that the Nordic family businesses balance conservatism with development. Families link their business with their identity, and are unwilling to leave the family businesses even in poor economic states. When they face challenges, family businesses of the region look for new directions to renew themselves, their communities, and their economies.

\section{Insights from the CASE Project}

One of the most compelling insights from the CASE Project is the cross-cultural differences in family involvement. We will summarize the core CASE findings on each of the nine dimensions of family business in the three regional clusters.

\section{Regulated boundary}

In the Anglo region, boundaries between the family and the business are highly regulated, and resource exchange is clearly determined. For example, Craig and Moores (2004) discuss the case of how the Dennis family in Australia professionalized their business by laying out clear boundaries regulating the relationship between the family members and the business.

In the Germanic cultures, boundaries between the family and the business are regulated, but only moderately so. The family business is seen as a vehicle to preserve the family legacy. Family members are willing to make sacrifices and go the extra mile for the success of the business. Peters and Buhalis (2008) find that family firms in the cluster have particular priorities and structures that often reflect the lifestyle the family wants to follow rather than rational business principles.

In the Nordic cultures, boundaries between the family and the business are the least regulated. Family business' decisions are kept within the family and the roles of family members within the firm may be quite informal, except in larger organizations. The family business is seen as the source of livelihood for the family, and the family is expected to be supportive especially when times are challenging for the business. Varamäki et al. (2003) note that in Nordic family businesses, the family's relationship with the business is seen as the most important resource and is responsible for carrying the inherent and hidden knowledge of the business and its operations.

\section{Business reputation}

In the Anglo region, business reputation is very important. Reputed business not only attracts and maintains high-quality external partners, but also serves as a magnet for attracting the family's successors into the business and maintaining cohesive relationships among family members involved in the business. Tokarczyk et al. (2008) underscore, based on their study of the US family businesses in the food and forest sector, how a family-like culture fosters an 'engaging stakeholder environment', which is translated into a market orientation, and ultimately a source of competitive advantage and long-term success.

In the Germanic cultures, business reputation is important, but the family dimension is also emphasized in order to cultivate trust and harmonious relationships with employees and other stakeholders, and as a more effective way than business orientation to manage conflict resolution. Uhlaner et al. (2004) report that the family in the region plays an important role in defining the 
relationship between the family business and several stakeholders, particularly employees, clients, and suppliers.

In the Nordic cultures, the family dimension is emphasized because the family business is seen as a vehicle for the family's identity. However, the families are willing to give up their preferences when required - for instance, though conservative, families are quick to embrace change if required. The family businesses tend to be pioneers; non-family members are encouraged to be innovative; family members advance to the leadership position based on their competence. In Norwegian family businesses, Mariussen et al. (1997) state that the commitment to entrepreneurial values must be balanced against the fortune of the family. The guardian of the fortune is often the mother who has the right to restrain the son from risk-taking.

\section{Bridging relationships}

In the Anglo region, bridging relationships are very important. The activities, markets, and lines of business selected by the family business are not usually similar to the focus of other families in the same community or ethnic lineage. Even if they are (as may happen when the family businesses are part of a regional industrial cluster), the relationship among different businesses tends to be business-centric, than family-centric. Moores and Mula (2000) observed a stage model amongst the Australian firms, as the family businesses evolve from an entrepreneurial stage to a collectivity stage, and then from a formalization and control stage to a structure elaboration and adaptation stage. Each stage accentuates the business-centrism.

In the Germanic cultures, there is a moderately high importance of bridging relationships. Family businesses tend to form strong bonds with their stakeholders, including suppliers, employees, customers, and the community, and seek to assure continuity of relationships with them. Dannhaeuser (1993) notes, however, that many family-operated firms in the region are members of 'Verbundgruppe'. The most important benefit is access to scale in the form of the combined purchasing power of the members. Verbundgruppen also offers territorial protection, and in recent years they have added optional services for their members, including shared advertising, product choice and computerized inventory control, training, and feasibility studies.

In the Nordic cultures, family businesses tend to operate in the traditional sectors where bridging relationships are moderately important. New business relationships are cultivated through spouses, involvement of spouses of children (especially sons-in-law), and non-family employees. Littunen (2003) found that the external personal networks were greater in the region's family businesses than non-family businesses during the critical first three years.

\section{Organizational professionalism}

In the Anglo region, professionalism tends to pervade the entire organization, in terms of people, procedures, strategies, systems, technologies, governance, and culture. Professional managers and employees are empowered to make strategic and operational decisions, as appropriate to their positions within the organization and experience/training. Craig and Moores (2004) noted that in their Australian case study the professionalization process was challenging because of its comprehensive nature and requirement for the owners to learn to let go.

In the Germanic cultures, professionalism is again high. Faster growing family businesses face pressure to involve non-family employees in managerial decisions and strategic planning, and may invest in training to enable this. Neubaurer (2008) reports that in the region larger firms have greater levels of integration of employees into core management processes. Smaller 
family firms, though, often fail to consult with staff or to delegate decision-making. Upon success and growth, all family businesses must rely upon non-family talent to maintain the firm.

In the Nordic cultures, professionalism is only moderately high. Professional managers and employees are empowered to make operational decisions, and participate actively in the strategic decisions. However, their decisions may be subject to scrutiny by the family managers, which may be accepted only to the extent that they have successfully cultivated long-term relationships with the family. Professionals may be advanced to the leadership positions, especially when successors are not available, though they are expected to show commitment to the family's business plan and goals. Littunen (2003) concludes that a network-building management style was commonly stressed by family firms, whereas a group management style was more emphasized in non-family firms. In other words, the family firms obtain ideas on how to manage their firms from discussions with customers, business contacts, and specialists.

\section{Regulated family power}

In the Anglo region, the exercise of power by the family tends to be highly regulated. Ownership is structured to enable easy exit by any family member from the family business. Opportunities are included for the equity share to be bought out by other family members, or by another strategic investor. In terms of management, emphasis is placed on family members preparing themselves for the businesses' needs rather than on the business creating positions for family members (e.g. pursuing excessive diversification simply to accommodate family members).

In the Germanic cultures, regulation of the power that the family exercises is moderately high. Though most family businesses are under the exclusive control of the family, even the smaller family businesses are focused on selecting the best from among all potential successors. The family business tends to have its ownership concentrated among only a few members; this helps to regulate the power of the entire family. Family businesses offer a higher level of responsibility and compensation to the family members than is available outside, but they also expect the family members to develop family business-specific learning through education and experience. Burggraaf et al. (2008) note that, in the egalitarian Dutch culture, ownership is guided by the principle of commitment, which is regarded as the active involvement of all family owners regardless of whether or not they hold a position within the business.

In the Nordic cultures, the exercise of power by the family is again moderately high. In smaller family businesses, family members often play a supporting role in management notably by providing checks and balances. In larger family businesses, various family members may be invited to work independently in different parts of the family business, though the top leadership roles may be given to only those who demonstrate sufficient competence. Koulouvari (2008) documents that within a majority of the family owned media companies in the Nordic region, fewer than three family employees were employed within the business, even though the extent of family ownership in these firms ranged from 76 to 100 percent.

\section{Competitive succession}

In the Anglo region, inter-generational succession process tends to be competitive. Successors prepare themselves through education and work experience either inside the family business or externally. As found by Sharma et al. (2003), the availability of an individual who has the intention to become a successor leader within the family firm is one of the best predictors that $\mathrm{s} / \mathrm{he}$ will 
actually do so. The point, however, is that offspring of Anglo family businesses typically have options; they are rarely obligated - or obliged - to join the family firm. The criteria for succession are specified clearly, and the successors must demonstrate competence to earn leadership. Predecessors transfer their knowledge of running the family business to the successors, and assign responsibilities in accordance with the competence and interest of various family members. They are expected to gradually withdraw from the family business affairs as the successors learn and gain knowledge about those affairs.

In the Germanic cultures, the inter-generational succession process tends to have a moderately high level of competitiveness. Successors are encouraged to take specialized academic courses and internships in areas related to the family business and to work for a few months in other companies nationally and internationally in order to learn new ideas and to bring innovative knowledge to the family business. Though ownership may be transferred to all the siblings in an egalitarian manner (and multiple generations of the family members may be engaged in the business), in most cases, there are only a few owners. In the family businesses that are led by males, succession usually is ceded to the male son; but an external sale or a management buy-out may be pursued, especially when financial limitations restrict the interest of the family members in the business. Glauben et al. (2004) note that human capital on Germanic family farms is often acquired in childhood as a by-product of growing up and that this is transferred through succession.

In the Nordic cultures, inter-generational succession tends to be moderately competitive. Successors are expected to prepare themselves through education, being socialized into the networks of the family business, and by demonstrating their competence through working within the family business. Increasingly, successors are allowed to participate in major decision-making in order to keep them engaged. Succession is usually passed to the son, and if there is no son, then the son-in-law may become the successor. Malinen and Stenholm's (2008) research in Finland suggests that incumbents and successors had similar opinions about entrepreneurship, an entrepreneurship career, family business succession, and the future of their business, thus lending credence to the saying 'like father, like son'.

\section{Gender-centered leadership}

Women play a fairly active leadership role in Anglo family businesses, especially if they are competent and interested in participating in the family business. Daughters are likely to be granted equal rights to the family estate, even if sons are also present. In principle, they also have equal rights to participate in the governance of the family business. They are offered senior management positions and allowed independent decision-making without needing to report to the male members. In practice, however, the roles may remain structured in a masculine manner, making it unviable for many daughters to be actively engaged in the family businesses at senior positions. As wives, women often help develop business systems to take care of their families and minimize the role carryover conflict, such as by seeking greater team leadership, smaller hierarchies, and enhanced communication. This is required because, as Smyrnios et al. (2003) report, family intrudes on US women's work lives whereas work spills over into the family lives of men. As such, women perceive a higher level of conflict between work and family responsibilities within the family businesses.

Women play a moderately important role in Germanic family businesses. Though daughters were traditionally excluded from succession, it is now becoming common for daughters to succeed, especially in situations where both the father and mother are actively involved in the family business. Burggraaf et al. (2008) report that in the region only 8 percent of all CEOs of medium-size 
family businesses are female, although almost 63 percent of all spouses work in the family business. The most important roles of the spouse (wife) in the family business are that of confidant(e) and adviser. The wife's active participation in the family business is seen as enhancing the family's social status, and assuring the success of the firm in a competitive environment. Wives tend to help family businesses pursue innovations, renew themselves, and become more professional, by helping to open new domains and opportunities.

Women play a moderate role in Nordic family businesses - though their role is active, it is mostly in supportive positions. While Nordic societies are characterized by relatively high gender equality in the formal arenas of societal life (i.e. politics, legislation, and working life participation), gender inequalities exist both within and outside of these formally equal structures and processes (Miettinen, 1997). As such, daughters were traditionally not given the family business CEO position; that position went to their husbands if they had no brother. Increasingly, daughters are being offered the $\mathrm{CEO}$ and line positions; however, they are expected to prove themselves by higher standards than those used for the sons.

\section{Operational resiliency}

In Anglo family businesses, the resiliency of the operating culture is moderately high. Competitive forces and professional managers allow for frequent changes in the strategic direction. Family businesses tend to pursue differentiation, specialization, organic growth, and related diversification strategies in order to weather cost-based competition. They are even pervasive in the less economically developed and in the more culturally cohesive communities, and are adapted to the environments of poverty, crime, and recession. Ogbonna and Harris (2005) report in their case study of a mature UK family business that operational resiliency was not important historically, but became a priority during the 1990s in response to economic recession.

In Germanic family businesses, the resiliency of the operating culture is moderately high. Major changes in the direction of family business are facilitated by the women of the family, successors, and professional managers. Family businesses tend to have related diversification, operating in craft-based industries as well as in related servicing and trading. Different members develop competencies in different domains enabling resiliency. In the region, the family-operated firm continues to be the dominant commercial institution. Dannhaeuser (1993) notes three counterbalancing factors. First, there is a historically derived cultural ideal eulogizing the family in general and the family firm in particular, which together with the political pressure of the commercial Mittelstand, has resulted in support programs by the State. Second, traditions exist for decades that have been associated with the family-operated firm and that, after having undergone some changes, continue to favor this type of enterprise. They include a shift of the internal division of labor toward the wife/husband team, a reinforced tendency to combine handicraft with retail trade, and the continuing (even if reduced) importance of the apprenticeship system. Third, there are the successful attempts made by operators of family firms to contractually affiliate themselves with the corporate supply side without totally losing their independence.

In Nordic family businesses, resiliency of the operating culture is moderately high. The farmers from the Nordic region always kept their farms despite bad economic conditions because of their strong bonds to the farm or traditions (Silvasti, 2003). On the other hand, major changes in the direction of family business can occur not only at the time of succession, but also when clients or the situation so demand. While they operate in traditional sectors, they are innovative and willing and able to make changes to remain competitive, including introducing new technologies and new 
techniques. The concentration of ownership within the family helps promote motivation and loyalty, commitment, long-term plans, and self-assessment. Consequently, family businesses are able to achieve growth on par with non-family businesses (Harju and Heinonen, 2008).

\section{Contextual embeddedness}

Family businesses in all three cultures demonstrate contextual embeddedness. Cohesiveness in culture, extending to all stakeholders, including family, business, community, business partners, and employees is favored, as opposed to heterogeneity and distance.

In the Anglo context, past research suggests the importance of shareholders as key stakeholders. Contextual embeddedness has an important influence on the organizational goals, attitudes, and practices of Anglo firms, as shareholder values get imprinted on the family business (Selznick, 1956). As an example, in a case study by Ogbonna and Harris (2005), the business owner (of the Quaker tradition) espoused values of equality, simplicity, harmony, paternalism (stewardship) and community, which were reflected in the philosophies and policies he brought to his paint and decorating supplies business in the UK.

In the Germanic region, stakeholder context is guided by a distinctive co-determination model which is characterized by a joint historical influence of family and business partners on the one hand and community and employees on the other. Dannhaeuser (1993) observes that a sense of history can create the justification for operators to continue the firm as a family affair across generations. Reinforced by family solidarity, this aided in the survival of the family firms during such crisis periods as post-First World War inflation. For these firms, keeping the enterprise under family control was just as important as the firm's survival, and children have been placed under subsequent pressure to keep the family firm alive.

Similarly, in the context of Nordic region, the external influence of community and ecological stakeholders is even stronger, which gets reflected in strong environmental and social consciousness amongst the region's businesses. The family businesses are particularly sensitive to this external influence. Malinen and Stenholm (2008) report that family firms considered three values and practices (i.e. monitoring environmental changes, continuously improving practices, and cooperation with subcontractors and customers) as more important than non-family firms did. Among these, the most important was environmental monitoring.

\section{Discussion}

In summary, the Anglo and Nordic models represent two contrasting forms of family businesses, while the Germanic model reflects a quasi-hybrid form. This can be seen from Table 2 that summarizes our findings.

In the Anglo region, there is a high degree of boundary regulation between the family and the business, the emphasis is on business reputation, bridging relationships are highly important, the exercise of power by the family is highly regulated, the succession process tends to be competitive, and leadership tends to be fairly gender-centered. In contrast, in Nordic region, there is lower regulation of boundary between the family and the business, family reputation receives greater regard, bonding relationships are more important, the exercise of power by the family is less regulated, the succession process tends to be more cooperative, and leadership tends to be less gender-centered than in the Anglo region. Finally, in Germanic region, the situation tends to be between the other two regions. Only in terms of operational resiliency and contextual embeddedness does one finds similarity amongst the three regions - in each 
Table 2. CASE family business dimensions for Anglo, Germanic, and Nordic Europe

\begin{tabular}{llll}
\hline & Anglo & Germanic & Nordic \\
\hline Regulated boundary & High & Moderately high & Moderate \\
Business reputation & High & Moderately high & Moderate \\
Bridging relationships & High & Moderately high & Moderate \\
Organizational professionalism & High & High & Moderately high \\
Regulated family power & High & Moderately high & Moderately high \\
Competitive succession & High & Moderately high & Moderate \\
Gender-centered leadership & Moderately high & Moderately high & Moderate \\
Operational resiliency & Moderately high & Moderately high & Moderately high \\
Contextual embeddedness & High & High & High \\
\hline
\end{tabular}

region, the family firms tend to be fairly resilient and reflect characteristics typical of their local contexts. However, as noted earlier, the resiliency mechanisms and the local context in each region have their distinctive features that play into the salient distinguishing characteristics of the family businesses in respective regions.

The distinctive features of family businesses in the three regions may be correlated with the cultural characteristics of these regions. A high degree of regulation found in the Anglo family businesses may be reflective of the cultural concern with the risks of nepotism; similarly emphasis on professionalism and business reputation may be related to achievement motivation. Also, competitive succession may be idealized because of the rejection of institutional collectivism, and gender-centered leadership may be idealized because of the endorsement of gender egalitarianism. The following vignette focuses on the differing cultural norm in the Nordic region on gender succession and the female response to disappointment.

Abelone Handsel, daughter of Alberte Handsel, has worked for her father's second-generation family business, for the past six years as the head of operations and technology. Her brother, Albert, who graduated with a business degree, has worked in the business for the past two years as a Materials Manager. Alberte is approaching 60 and wants to retire. Because of her experience and time spent in the family business, Abelone is confident that she will be the new president of the family business. However, when the family members meet to discuss the successor, most of the family members support Albert as the next president. Abelone is confused and wonders why her inexperienced brother is being given preference. She is extremely disappointed, however, she accepts the family's decision.

This vignette clearly demonstrates how daughters are traditionally excluded from succession and it supports Miettinen's (1997) findings that in Nordic societies, gender inequalities exist both within and outside of the formally equal structures and processes.

The lower degree of regulation found in Nordic businesses may be reflective of the cultural feature of institutional collectivism; performance is achieved not only through professionalism and business reputation but also through egalitarian non-dominating networks. These collective networks also result in a somewhat cooperative model for succession; however, stronger standards for gender egalitarianism in the formal sphere have had only limited impact on the informal family sphere. The following vignette offers an example of how these cultural differences can creep into two generations of a single family when emigration has occurred and the younger generation has adopted many of the cultural values of the new country. 
Christian Gustafsson emigrated from Finland to the United States 25 years ago to seek a better life for his family. He and his wife launched a horticulture business that flourished and currently employs 75 employees, including both extended family members and a majority of immigrants. After graduating with a business degree, Niklas, Gustafsson's US-born son, has many ideas for improving the family business, including reorganizing the firm using a more formal structure with clearly defined rules and hiring policies. Niklas believes that hiring more highly skilled, English-speaking employees over hardworking immigrants will result in long-term business growth and increased profitability. While Christian Gustafsson appreciates his son's ideas, he has been profoundly impacted by his personal experiences as an immigrant and seeks to give others the opportunity to succeed ... even if it means sacrificing some business opportunities and future growth.

Christian Gustafsson, because of his Nordic background, prefers giving back to community, reflecting his sense of collectivism. He places more importance on giving someone an opportunity than structuring the organization. On the other hand, his son who is born and educated in the US is high on professionalism and is more future oriented.

The GLOBE results reveal the Germanic cluster to be distinguished by strong uncertainty avoidance, performance orientation, future orientation and assertiveness - a hallmark of its mechanistic orientation. Mechanistic orientation implies that family businesses leverage competent resources, and yet are sensitive to the value of preparing the family members to carry forward the family's legacy as a way to sustain and enhance performance. Consequently, an idealized form may have evolved in this cluster that combines features of the Anglo cluster that are intended to minimize the family's arbitrariness and maximize the business prospects with features of the Nordic cluster intended to leverage family as well as non-family networks. The following vignette highlights the practical implications of these cultural differences.

John Dean, a middle-level executive of a medium-sized family business in the US, was given the task of visiting a possible German supplier in Frankfurt, Germany. A meeting with the President of the firm (Torsten Becker) was set for a Thursday morning at 9:00 a.m. Upon his arrival (10:00 a.m.), he addressed Becker by his first name. During the meeting, Dean explained how entrepreneurial his company was, stressing how its suppliers were encouraged to be equally creative in developing new ideas and concepts. Over the next hour, Dean furnished details about his firm's accomplishments and why the German company should consider signing a supplier partnership. Finally, he produced an agreement, presenting it to the President for his signature. Dean was taken aback when the President requested more time. After Dean departed, he telephoned his boss (in the US), telling him how shocked and disappointed he was that that no agreement was reached.

Unlike the Anglo and Nordic cultures which are typically 'high risk-taking' cultures, the Germanic culture tends to be traditionally cautious about new ideas and concepts. Also, not sending a senior manager, being late for the appointment, greeting the President by his first name, and pushing for an agreement are cultural blunders that should have been avoided.

\section{Implications}

Our findings have specific implications for four domains of cross-cultural research: the convergence/divergence debate, (b) the spirit of Protestantism discourse, (c) the literature on culturally implicit theories, and (d) family business management. 


\section{Implications for convergence/divergence debate}

The convergence research and perspective would argue that, as countries industrialize, the strategic behavior of businesses tends to become more similar (i.e. 'converge') because people tend to embrace common values with respect to economic activity and work-related behavior (England and Lee, 1974; Pascale and Maguire, 1980). Most scholars assume that the convergence tends toward the Anglo neo-liberalism model, based on a view that American shareholder capitalism is the most efficient model (Kerr et al., 1964). According to some (Meyer and Rowan, 1977; Useem, 1996), those companies and countries that do not follow this approach will suffer a declining global competitiveness.

The divergence perspective posits that national culture, rather than economic ideology or technological growth, is (and will continue to be) the dominant force in shaping the values, beliefs, and attitudes of managers within a country (Hofstede, 2001; Laurent, 1983). Each nation supports a distinct strategic perspective that allows firms from different nations to compete on variables aside from price (Ricks et al., 1990). Most divergence scholars hold that because varying cultural values present an obstacle to convergence, divergence is a second-best solution and will impede the economic development of non-Anglo nations (Lundvall and Tomlinson, 2000).

Nations in the Anglo cluster have been heavily influenced by Calvinism and post-Calvin beliefs, such as Puritanism (Weber, 1904/5). On the other hand, a vast majority of the populace in Nordic nations belongs to the Lutheran Church (Becker and Wobmann, 2007), and the Germanic region seems to contain a mix of Lutheran and Calvinist influences. Consequently, should we expect convergence in forms and formats of family business due to the shared Protestant cultures? Or should family businesses in the three clusters demonstrate divergence, based on various factors, including the varying forms of Protestantism?

Our findings do point to important divergences in the characteristics of family business, even though some similarities are also noticeable particularly in reference to resiliency and the context. Hence, we can only draw one of two conclusions. (1) Families (and family businesses) are embedded in their communities and are, therefore, resistant to change, so the convergence process may be occurring more slowly or may be more challenging due to the presence of obstacles to change. (2) Families (and family businesses) truly are different as a result of their national cultures, and will remain so. This perspective suggests that family businesses will need to find their own culture-specific competitive advantage to achieve future success.

\section{Implications for the spirit of Protestantism}

Weber (1904/5) asked why work came to be cherished in the West. Up until medieval times, the purpose of work was to meet the physical needs of one's family and community (Tilgher, 1930). Martin Luther's Protestant Reformation introduced the belief that people could serve God through their work, i.e. work was a calling (Lipset, 1992). This meant that a person should work diligently in his own family's occupation and business, and should not change that. To Lutheran Reform, John Calvin added the belief in Election - that God has chosen people to participate in the reshaping the world by being active, austere, and hard-working (Tilgher, 1930). Selection of an occupation and pursuing it to achieve the greatest profit possible was considered by Calvinists to be a religious duty, even if that meant breaking away from the family business or profession. The Protestant Reform encouraged investments in education (Becker and Wobmann, 2007) to help people learn their vocations and to achieve the greatest profit for reinvestment. The work and writings of John Calvin, who 
was a lawyer by training, were influential in establishing a loose consensus among various groups, primarily in Germanic Europe.

\section{Implications for culturally implicit theories}

Though Anglo and Northern European regions share the spirit of Protestantism, Luther's Protestant Reform and John Calvin's doctrine of election introduced variations (i.e. philosophies and interpretations) on the purpose of work and the possibility of eternal life (e.g. Lipset, 1992; Tilgher, 1930). Consequently, we are led to ask, do people in nations influenced by the Protestant religious institutions hold certain cultural beliefs, presuppositions, and implicit theories about the science of human behavior and the spirit of family business (cf. Furnham, 1988) based upon the religious tradition in which their culture is grounded?

The philosophies and religious influence (i.e. Protestant ethic) of Luther and Calvin may be described as culturally implicit theories. Culturally implicit theories derive from the cultural traditions and expectations, and are culturally programmed constructions about human behavior and social forces (see Runco and Johnson, 2002) that have been found to be highly stable over time (Franiuk et al., 2002). Thus, we might anticipate that Calvinism and post-Calvinistic-dominated culturally implicit theory could be challenging for family businesses, because of the apparent requirement that successors must choose to break away or to jump into another line of business if other, more profitable, opportunities exist. When they do, we might anticipate that, based on Calvinism's legalistic thinking, business arrangements and relationships might be highly proscribed. On the other hand, Lutheran-dominated culturally implicit theory is likely to encourage the successors to continue with the family tradition by joining the family business and keeping the traditional lines of business.

Our findings do point to the characteristics of family businesses in the three regions that might be correlated with the distinctive forms of Protestantism. Anglo family businesses appear to be most supportive of allowing successors to break away or to jump into other lines of business if more profitable opportunities exist. On the other hand, Nordic family businesses are more prone to promote the continuity of the family business as is - by encouraging successors to join the business and stay with traditional lines. Germanic family businesses are in the middle - where the profitable opportunities are idealized, as is the family character of the family business.

We also find that Anglo family businesses display regulated family involvement - which may reflect Calvinism - clearly specified criteria and boundaries allow access to market resources on terms equivalent to those enjoyed by non-family firms. Nordic European firms, on the other hand, display equilibrating family involvement, where the wife balances the risk profile of her husband's initiatives, and the mother balances the conservative business culture set by the parents and the growth aspirations of her children. Here, the family business provides security to the family while also helping to rejuvenate traditional sectors of the economy.

\section{Implications for family business management}

In family business management, research, and education, it would be useful to reflect upon the impact cultural and contextual differences may have on the relevance of general practices and theories of family business. Family business practitioners face considerable challenges trying to compete with the professionally run and better financially endowed multinational enterprises. Balancing family involvement with growth and professionalism is difficult. Usually, family businesses seek solutions from within their community based on the exchange of insights during social 
and community events. The unique culturally sensitive solutions in alternative regions can provide new ways of reconciling apparently conflicting goals. Family businesses may also gain leadership by sharing their own culturally sensitive solutions with family businesses from other regions. Understanding the cultural aspects of family businesses would also aid in forming international alliances and partnerships with family businesses from different cultures. Since the institution of family is very closely intertwined with that of culture, and is, in fact, the founding building bloc of societal culture, it is important to use a culture-sensitive lens while assessing family businesses and seeking to develop strategies and resolve challenges facing them. It is also vital that the family aspect be woven into the study of cross-cultural management and international management. This is because families and cultures are co-embedded - families define cultures as much as the culture defines families.

\section{Limitations}

The analysis presented in this paper is subject to two major limitations. First, our analysis has treated the clusters as if they were internally homogeneous. While Gupta and Hanges (2004) demonstrated statistical validity of the clusters, they also found substantial variations within the clusters. The differences among clusters in terms of societal culture were as large as the variations within clusters. However, the within-cluster models of family businesses along with the comparative models presented here may lead us to a unique multi-level perspective of culture and family businesses.

A second limitation concerns the scope of the CASE research. Essentially, the CASE results are based on a thematic content analysis of ten selected articles on the family businesses in each cluster. CASE results, thus, present a snapshot of family businesses in each cluster - as captured by the sample. Certainly, a different sample could ultimately lead to some of our conclusions being identified as less generalizable than they appear to be here. Still, such depictions help us to better understand family businesses in each cluster (Ashkanasy, 2002). Future researchers should continue to study family businesses, both qualitatively and quantitatively, to enable a better understanding of the diversities in family business models.

\section{Conclusions}

Our conclusion is that the family businesses across the three clusters discussed here have culturally sensitive characteristics. It will be useful for future researchers to examine if there are other factors that might account for the observed divergence. For example, Weber (1904/5) stated that the Protestant ethic led to the pursuit of wealth. More recent research (Becker and Wobmann, 2007), however, suggests that because the Protestant ethic was also coupled with educational investments, these educational investments were responsible for growth and wealth. Consequently, could other factors, in addition to culture, surround the divergence?

\section{References}

Ashkanasy N (2002). Leadership in the Asian century: lessons from GLOBE. International Journal of Organizational Behavior 5(3): 150-63.

Barbot M-C, Bayad M, Bourguiba M, and Schmitt C (2005) Comparative Entrepreneurship: The Case of Father-to-Daughter Family Business Transmission in France and Tunisia, Working Paper, Small Business Advancement National Center, University of Arkansas: http://www.sbaer.uca.edu/research/icsb/ 2005/013.pdf. 
Baring G (1992) Characteristics of Australian Family Business. Working Paper Series, 4/92. Melbourne: Monash University.

Becker SO and Wobmann L (2007) Was Weber Wrong? A Human Capital Theory of Protestant Economic History. Working Paper. Munich: IFO Institute, University of Munich.

Burggraaf W, Floren RH and Geerlings JR (2008) Righteousness in ownership transfer: a cultural perspective. In: Gupta V, Levenburg N, Moore L, Motwani J and Schwarz T (eds) Culturally-Sensitive Models of Family Business in Germanic Europe: A Compendium Using the GLOBE Paradigm. Hyderabad: ICFAI University Press, 69-89.

Chrisman JJ, Chua JH and Steier LP (2003) An introduction to theories of family business. Journal of Business Venturing 18: 441-8.

Craig J and Moores K (2004) The professionalization process in family business: the Dennis family corporation case. Family Business Journal: Case Book Annual 91-122.

Dannhaeuser N (1993) The survival of family-operated firms under developed conditions: the case of Hassfurt, Germany. Journal of Developing Areas 27: 307-28.

Dunemann M and Barett R (2004) Family Business and Succession Planning: A Review of Literature. Melbourne: Family and Small Business Research Unit, Faculty of Business and Economics, Monash University.

Einola K and Turgeon N (2000) Scandinavian Television Markets: A Regional Perspective. Working Paper, 2000-05. Montreal: CETAI-HEC.

England GW and Lee R (1974) The relationship between managerial values and managerial success in the United States, Japan, India, and Australia. Journal of Applied Psychology 59(4): 411-19.

Flören RH (1998) The significance of family business in the Netherlands. Family Business Review 11: 121-34.

Franiuk R, Cohen D and Pomerantz EM (2002) Implicit theories of relationships: implications for relationship satisfaction and longevity. Personal Relationships 9(4): 345-67.

Furnham A (1988) Lay Theories: Everyday Understanding of Problems in the Social Sciences. New York: Pergamon.

Gersick K, Davis J, Hampton M and Lansberg I (1997) Generation to Generation: Life Cycles of the Family Business. Boston: Harvard Business School.

Glauben T, Tietje H and Weiss C (2004) Intergenerational succession in farm households: evidence from upper Austria. Review of Economics of the Household 2: 443-61.

Gupta V and Hanges PJ (2004) Regional and climate clustering of societal cultures. In: House RJ, Hanges PJ, Javidan M, Dorfman PW, and Gupta V (eds) Culture, Leadership, and Organizations: The GLOBE Study of 62 Societies. Thousand Oaks, CA: Sage Publications, 178-218.

Gupta V, Levenburg N, Moore L, Motwani J and Schwarz T (2008a) Culturally-Sensitive Models of Family Business in Anglo region: A Compendium Using the GLOBE Paradigm. Hyderabad: ICFAI University Press.

Gupta V, Levenburg N, Moore L, Motwani J and Schwarz T (2008b) Culturally-Sensitive Models of Family Business in Germanic Europe: A Compendium Using the GLOBE Paradigm. Hyderabad, India: ICFAI University Press.

Gupta V, Levenburg N, Moore L, Motwani J and Schwarz T (2008c) Culturally-Sensitive Models of Family Business in Nordic Europe: A Compendium Using the GLOBE Paradigm. Hyderabad, India: ICFAI University Press.

Gupta V and Levenburg N (2010). A Thematic Analysis of Cultural Variations in Family Businesses: The CASE Project. Family Business Review 23(2): 155-69.

Harju J and Heinonen J (2008) Analyzing Finnish family business performance. In: Gupta V, Levenburg N, Moore L, Motwani J and Schwarz T (eds) Culturally-Sensitive Models of Family Business in Nordic Europe: A Compendium Using the GLOBE Paradigm. Hyderabad, India: ICFAI University Press, 89-124.

Harris R, Martinez J and Ward J (1994) Is strategy different for the family-owned business? Family Business Review 7(2): 159-74.

Hofstede G (2001) Culture's Consequences, Comparing Values, Behaviors, Institutions, and Organizations across Nations. Thousand Oaks, CA: Sage Publications. 
House RJ, Hanges PJ, Javidan M, Dorfman PW and Gupta V (eds) (2004) Culture, Leadership, and Organizations: The GLOBE Study of 62 Cultures. Thousand Oaks, CA: Sage Publications.

Kerr C, Dunlop JT, Harbison F and Myers CA (1964) Industrialism and Industrial Man. New York: Oxford University Press.

Koulouvari P (2008) Family Owned Media Companies in the Nordic Countries: A Portrait of Structures and Characteristics of 25 Firms. In: Gupta V, Levenburg N, Moore L, Motwani J, and Schwarz T (2008c) Culturally-Sensitive Models of Family Business in Nordic Europe: A Compendium Using the GLOBE Paradigm. Hyderabad: ICFAI University Press, 17-39.

Laurent A (1983) The cultural diversity of western conceptions of management. International Studies of Management and Organization 13: 75-96.

Lipset SM (1992) The work ethic, then and now. Journal of Labor Research 13(1): 45-55.

Littunen H (2003) Management capabilities and environmental characteristics in the critical operational phase of entrepreneurship - a comparison between Finnish family and non-family firms. Family Business Review 16(3): 183-96.

Lundvall BÅ and Tomlinson M (2000) On the convergence and divergence of national systems of innovation. Paper presented at the Volkswagen Foundation Symposium on Prospects and Challenges for Research on Innovation, Berlin, 8-9 June.

Lussier RN and Sonfield MC (2004) Family business characteristics and management practices: an analysis of covariance study. Academy of Entrepreneurship Journal 10(1): 827-44.

Malinen P and Stenholm P (2008) Transfer of entrepreneurship in the Finnish small family business succession context. In Gupta V, Levenburg N, Moore L, Motwani J and Schwarz T (eds) Culturally-Sensitive Models of Family Business in Nordic Europe: A Compendium Using the GLOBE Paradigm. Hyderabad: ICFAI University Press, 70-88.

Mariussen A, Wheelock J and Baines S (1997) The family business tradition in Britain and Norway: modernization and reinvention. International Studies of Management and Organization 27(3): 64-85.

Meyer JW and Rowan B (1977) Institutionalized organizations: formal structure as myth and ceremony. American Journal of Sociology 83: 340-63.

Miettinen A (1997) Work and the family: Data on women and men in Europe. Working Papers E2/1997, Helsinki: The Population Research Institute, the family federation of Finland.

Moores K and Mula JM (2000) The salience of market, bureaucratic and clan controls in the management of family firm transitions: some tentative Australian evidence. Family Business Review 91-106.

Neubauer F and Lank AG (1998) The Family Business: Its Governance for Sustainability. London: Macmillan Press.

Neubauer, H. (2008). Family businesses and perspectives on corporate continuity - Reflections on the situation in Continental Europe. In: Gupta, V., Levenburg, N., Moore, L., Motwani, J. \& Schwarz, Th. (eds) Culturally-Sensitive Models of Family Business in Germanic Europe - A Compendium using the Globe Paradigm, Hyderabad, 109-132.

Ogbonna E and Harris LC (2005) The adoption and use of information technology: a longitudinal study of a mature family firm. New Technology, Work and Employment 20(1): 2-18.

Pascale RT and Maguire MA (1980) Comparison of selected work factors in Japan and the United States. Human Relations 33: 433-55.

Peters M and Buhalis D (2008) Skill development in Austrian family hotel businesses. In: Gupta V, Levenburg N, Moore L, Motwani J, and Schwarz T (eds) Culturally-Sensitive Models of Family Business in Germanic Europe: A Compendium Using the GLOBE Paradigm. Hyderabad: ICFAI University Press, 48-68.

Pistrui D, Welsch HP, Wintermantel O, Liao J and Pohl HJ (2000) Entrepreneurial orientation and family forces in the new Germany: similarities and differences between East and West German entrepreneurs. Family Business Review 13(3): 251-64.

Ricks DA, Toyne B and Martinez Z (1990) Recent developments in international management research. Journal of Management 16(2): 219-53. 
Ronen S and Shenkar O (1985) Clustering countries on attitudinal dimensions: A review and synthesis. Academy of Management Review, 10: 435-454.

Runco MA and Johnson DJ (2002) Parents' and teachers' implicit theories of children's creativity: a cross-cultural perspective. Creativity Research Journal 14(3-4): 427-38.

Schake LM (1998) The Schakes of La Charette: 1855-1996: http://www.rootsweb.com/ mowarren/schake/ partlb.html.

Selznick P (1956) Leadership in administration, Berkeley, CA: University of California Press.

Sharma P, Chrisman JJ and Chua JH (2003) Succession planning as planned behavior: some empirical results. Family Business Review 16(1): 1-15.

Silvasti T (2003) Bending borders of gendered labour division on farms: the case of Finland. Sociologia Ruralis 43(2): 154-66.

Smyrnios K, Tanewski G, Romano C, Karofsky P, Millen R and Yilmaz MR (2003) Work-family conflict: a study of American and Australian family businesses. Family Business Review 16(1): 35-51.

Stoy Hayward (1989) Staying the Course. London: Stoy Hayward.

Tilgher A (1930) Homo Faber: Work through the Ages, tr. DC Fisher. New York: Harcourt Brace.

Tokarczyk J, Hansen E, Green M and Down J (2008) Considering 'familiness' in market orientations and success: a resource-based view. In: Gupta V, Levenburg N, Moore L, Motwani J, and Schwarz T (eds) Culturally-Sensitive Models of Family Business in Anglo Region: A Compendium Using the GLOBE Paradigm. Hyderabad, India: ICFAI University Press, 214-36.

Uhlaner LM, van Goor-Balk HJM and Masurel E (2004) Family business and corporate social responsibility in a sample of Dutch firms. Journal of Small Business and Enterprise Development 11(2): 186-94.

Useem M (1996) Investor Capitalism: How Money Managers are Changing the Face of Corporate America. New York: Basic Books.

Varamäki E, Pihkala T and Routamaa V (2003) Stages of transferring knowledge in small family business successions. Proceedings of Family Business Network 14th Annual World Conference, Lausanne.

Weber M (1904/5) Die protestantische Ethik und der "Geist" des Kapitalismus. Archiv für Sozialwissenschaft und Sozialpolitik 20: 1-54 and 21: 1-110. Repr. in Gesammelte Aufsätze zur Religionssoziologie (1920), 17-206. Eng. tr.: The Protestant Ethic and the Spirit of Capitalism, tr. Talcott Parsons. London: Routledge Classics, 1930/2000. 